DOI: 10.20472/LPC.2018.003.001

\author{
GRAEME AUTON \\ University of Redlands, United States
}

\title{
NATIONALISM, POPULISM, REALISM AND THE INTENSIFICATION OF EAST ASIA'S MARITIME DISPUTES
}

\begin{abstract}
:
The neo-realist paradigm in international relations scholarship holds that sovereign states are rational, unitary, value-maximizing actors capable of understanding and rank-ordering their tangible national interests while distinguishing between short- and long-term goals. In the neo-realist view, territorial conflicts, unless involving central security concerns, will be subordinated to larger foreign policy objectives. Neo-liberals, on the other hand, argue that the growth of trade and economic interdependence is conducive to cooperation. "Trade dependency" on a state with which there is a territorial conflict will lead to sublimation, sidelining or delayed resolution of the dispute without the threat or use of force. This paper analyzes three of East Asia's high-profile maritime disputes, those over the Southern Kurlies/Northern Territories (Russia and Japan), Dokdo/Takeshima (South Korea/Japan), and Diaoyu/Senkaku (China/Japan). The paper demonstrates that, to an increasing degree, nationalist and populist sentiment - rather than neo-realist or neo-liberal calculation - has been the prime mover in each of these conflicts. The four regional players - China, Japan, South Korea and Russia - have politically invested far more in these islands than an objective analysis would seem to warrant, leading to intensified diplomatic conflict, hampered cooperation, emotion-driven domestic populism, and the possibility of future military action. The paper rejects the reasoning of some recent scholarship on the resolution of maritime disputes. It argues that the increasing salience of populist nationalism as a force hampering the resolution of maritime conflict is part of a global trend in the second decade of the 21st century.
\end{abstract}

\section{Keywords:}

maritime conflict; conflict resolution; nationalism; populism; neo-realism; neo-liberalism; constructivism; social identity theory; Asia-Pacific

JEL Classification: D74, D81, H12 
The neo-realist paradigm in international relations scholarship holds that sovereign states are rational, unitary, value-maximizing actors capable of rank ordering their tangible national interests and distinguishing between short- and long-term goals. ${ }^{1}$ Since the end of the Cold War, China, Japan, South Korea and Russia - the major "resident" powers in East Asia - have experienced significantly greater economic interdependence and a growing confluence of geopolitical concerns, among them a changing regional balance of power. Several factors have supported practical East Asian regionalism: the economic complementarity of regional states; geographic proximity; rates of economic growth; tangible need for infrastructure development; shared energy dependency; and a growing willingness to consider policy coordination in some areas (as evidenced in the 2008-2015 Dazaifu, Beijing, Jeju, Tokyo and Seoul trilateral summits). All four states must find ways - political and diplomatic - to compensate for the relative decline of U.S. power in East Asia, despite the efforts of the Obama and Trump Administrations to reassert an American geo-strategic presence. Yet, regional cooperation has been hobbled. Efforts to explore the practical confluence of interests between Beijing, Tokyo, Seoul and Moscow have been repeatedly confounded by nationalist sentiment focused on territorial conflict and the "history question." ${ }^{2}$ While there have been short periods, such as the late 1990s, when it seemed remotely feasible to set past animosities and bureaucratic obstacles aside, and sublimate territorial disputes whose importance pales in comparison to the benefits of regional cooperation, divisions among the four powers have actually increased over the past decade. In all four countries (as in much of the rest of the world) domestic political sentiments have conspired to support a nationalist style of foreign policy that promotes conflict, is inimical to regional cooperation, and - at times - leads governments to behave in a manner inconsistent with what is arguably their long term best interest. ${ }^{3}$

International relations theory sheds light on these developments. Constructivist theorists argue that states and political leaders cling tenaciously to identities (not only of themselves, but also of allies and adversaries), and to the interests defined by those identities, in the face of sometimes dramatic changes in the "objective" circumstances of international politics. ${ }^{4}$ The persistence of identities and corresponding interests over time is explained by a variety of factors: constituencies that benefit from them; "asset specificities" (i.e., resource allocations, material and non-material, that benefit those constituencies with a stake in a continued set of identities); ${ }^{5}$ and "cognitive lag"

\footnotetext{
${ }^{1}$ See Kenneth N. Waltz, Theory of International Politics (Reading, Mass.: Addison-Wesley, 1979), particularly pp.194210; John J. Mearsheimer, The Tragedy of Great Power Politics (New York: W.W. Norton, 2001); and Stephen M. Walt, The Origins of Alliances (Ithaca: Cornell University Press, 1987).

2 See Michael R. Auslin, The End of the Asian Century: War, Stagnation, and the Risks to the World's Most Dynamic Region (New Haven: Yale University Press, 2017), pp.122-150.

3 lbid.

${ }^{4}$ See Alexander Wendt, "Anarchy is What States Make of It: The Social Construction of Power Politics," International Organization, vol.46, no.2 (Spring 1992), pp.391-425; Peter Katzenstein, The Culture of National Security (New York: Columbia University Press, 1996); Martha Finnemore, National Interests and International Society (Ithaca: Cornell University Press, 1996); Jeffrey W. Legro, Rethinking the World: Great Power Strategies and International Order (Ithaca: Cornell University Press, 2005); and Jae-Jung Suh, Power, Interest, and Identity in Military Alliances (New York: Palgrave Macmillan, 2007).

${ }^{5}$ See Suh, Power, Interest, and Identity in Military Alliances, pp.64, 138-144.
} 
(the failure of political leaders and foreign policy establishments to recognize and internalize change in a timely fashion). ${ }^{6}$ Jeffrey Legro has argued that significant changes in foreign policies are relatively rare, and are ultimately a product of policy expectations, national experience, and the availability of "replacement ideas." Such changes are difficult to achieve without a cathartic crisis or shock that forces policymakers to alter their frame of reference. In a similar vein, Mark $L$. Haas has argued that interstate conflict is a product of "ideological distance," a key determinant of which is social identity theory, which in turn explains miscommunication and misperception in the attempts of states to resolve their differences. ${ }^{8}$ The tendency to trust citizens of one's own state while distrusting those of another is important in explaining "the ubiquitous problem of uncertainty about others' intentions." 9 Such factors critically affect interstate communications, even when a government has resorted to "costly signals" to resolve a dispute - that is, has indicated a willingness to make concessions that are costly to its own national interests in order to resolve a conflict. ${ }^{10}$

Liberal and neo-liberal theorists have taken a different approach. Their argument is that the growth of trade and economic interdependence is conducive to cooperation, and that "trade dependency" on a state with which there is a territorial conflict is likely to lead to sublimation, sidelining or delayed resolution of a territorial dispute without the threat or use of force. ${ }^{11}$ Given East Asia's dramatic economic growth, and the equally dramatic growth of trade and investment between China, Japan, South Korea, and the ASEAN states, regional players have a strong incentive to cooperate in moderating their approach to territorial differences. This thesis (among others) has been tested with regard East Asian maritime territorial disputes by Min Gyo Koo. ${ }^{12}$ In

\footnotetext{
${ }^{6}$ On cognitive lag, see Graeme P. Auton and Wolfram F. Hanrieder, The Foreign Policies of West Germany, France, and Britain (Englewood Cliffs, N.J.: Prentice-Hall, 1980), pp.177-185.

7 See Legro, Rethinking the World, pp.13-17, 28-40.

8 See Mark L. Haas, The Ideological Origins of Great Power Politics, 1789-1989 (Ithaca: Cornell University Press, 2005), pp.4-39, 211-224.

9 lbid., p.12.

10 lbid., pp.12-13. Notes Raymond Cohen, "for a message to be correctly understood there must be sufficient similarity, if not identity, between the intention of the sender and meaning attributed by the receiver." Raymond Cohen,

Negotiating Across Cultures: Communication Obstacles in International Diplomacy (Washington, D.C.: U.S. Institute of Peace Press, 1991), p.20.

11 See Robert Keohane and Joseph Nye, Power and Interdependence: World Politics in Transition (Boston: Little, Brown, 1977); Robert Keohane, After Hegemony: Cooperation and Discord in the World Political Economy (Princeton: Princeton University Press, 2005); Kenichi Ohmae, The Borderless World: Power and Strategies in the Interlinked Economy (New York: Harper Business, 1993); Susan Strange, The Retreat of the State: The Diffusion of Power in the World Economy (Cambridge: Cambridge University Press, 1996); John R. Oneal, Frances H. Oneal, Zeev Maoz and Bruce M. Russett, "The Liberal Peace: Interdependence, Democracy, and International Conflict, 1950-1985," Journal of Peace Research 33:1 (1996), pp.11-28; John R. Oneal and Bruce M. Russett, "The Classical Liberals Were Right: Democracy, Interdependence, and Conflict, 1950-85,” International Studies Quarterly 41:2 (1997), pp.267-293.

12 See Min Gyo Koo, Island Disputes and Maritime Regime Building in East Asia: Between a Rock and a Hard Place (New York: Springer, 2010); and Koo, "Liberal Peace and the Scramble for the Rocks: The Dokdo/Takeshima, Senkaku-Diaoyu, and Paracel and Spratly Islands Disputes," University of Southern California Center for International Studies. Originally presented as a paper at the annual meeting of the American Political Science Association, Washington, D.C., September 3, 2005. See also M. Taylor Fravel, "Explaining Stability in the Senkaku (Diaoyu) Islands
} 
examining the Dokdo/Takeshima, Diaoyu/Senkaku and South China Sea disputes, he arrives at a mixed picture: in the case of Dokdo, "South Korea's trade dependence on Japan has a statistically significant impact on the dispute intensity. This indicates that the more dependent on Japan South Korea becomes for trade, the less likely the Dokdo/Takeshima dispute is to be escalated."13 For Diaoyu/Senkaku, however, the result is the opposite: "Japan's trade dependence on China has a statistically significant positive impact on the dispute intensity. This estimation result indicates that the more dependent on China Japan becomes for trade, the more likely the Senkaku/Diaoyu dispute is to be escalated. It is plausible that Japan may feel increasingly insecure, as one of its traditional power advantages - asymmetric trade relations with China in its favor - continues to erode." 14

For realists, of course, liberal peace theory based on trade and interdependence is an illusion: Closer economic ties are as likely to produce conflict as cooperation, since greater opportunities for interaction between states create more opportunities for discord, and since asymmetric interdependence between trade partners may generate conflict. ${ }^{15}$ For realists, disputes over territory are unlikely to be restrained by trade or interdependence. ${ }^{16}$ Rather, they involve calculations related to state power, the rank ordering of state interests, and the degree of domestic support that a government and its policies can enjoy.

My concern in this paper is not with the importance attached by realists and neo-realists to territorial conflict; that is beyond argument. Rather, my concern is with those cases in which a state's commitment to a territorial dispute contradicts realism's own dictums about the rank ordering of state interests and the rational pursuit of state power. Territorial disputes are a difficult species of international conflict because they go to the heart of a state's self-identity and frequently invoke domestic political sentiments. ${ }^{17}$ Moreover, such conflicts may be viewed in zero-sum terms by the protagonists, in a way that renders compromise or cooperation

Dispute," in Gerald Curtis, Ryosei Kokubun \& Wang Jisi, eds., Getting the Triangle Straight: Managing China-JapanU.S. Relations (Washington D.C.: Brookings Institution Press, pp. 144-164.

${ }^{13}$ Koo, "Liberal Peace and the Scramble for the Rocks," pp.23-24.

14 lbid., p.31.

15 See Dale C. Copeland, "Economic Interdependence and War: A Theory of Trade Expectations," International Security 20:4 (1996); Albert Hirschman, National Power and the Structure of Foreign Trade (Berkeley: University of California Press, 1980); Kenneth Waltz, "The Myth of Interdependence," in Charles Kindleberger, ed., The International Corporation (Cambridge: MIT Press, 1970); Christopher Layne, "Kant or Cant: The Myth of the Democratic Peace," International Security 19:2 (1994).

${ }^{16}$ See Robert Gilpin, War and Change in World Politics (Cambridge, Cambridge University Press, 1981), p.23.

"Throughout history a principal objective of states has been the conquest of territory in order to advance economic, security, and other interests ... states in all ages have sought to enlarge their control over territory and, by implication, their control over the international system." Gilpin's statement may be too categorical. For realists to be consistent, they must argue that the intensity of a state's commitment to a territorial conflict must be balanced against its other interests, some of which may take precedence.

17 See Paul K. Huth, Standing Your Ground: Territorial Disputes and International Conflict (Ann Arbor: University of Michigan Press, 1996); and Beth A. Simmons, "Capacity, Commitment, and Compliance: International Law and the Settlement of Territorial Disputes," Journal of Conflict Resolution 46:6 (2002), pp.829-856. 
exceedingly difficult. As M. Taylor Fravel states in his analysis of China's territorial differences with its neighbors, "territorial disputes bear on a state's national sovereignty and territorial integrity, its core interests. Historically, they have been the most common issue over which states collide and go to war. Decisions to cooperate or escalate in pursuit of a state's territorial claims have enormous consequences for peace and stability in international relations." 18 Of course, territorial disputes do not all bear equally on a state's "core" interests; some - including the disputes discussed in this paper - are arguably peripheral to the central geopolitical, geostrategic and economic concerns of the states involved in them. Moreover, maritime disputes of the kind discussed here are different from conflicts over land borders.

“. . . A maritime sovereignty dispute is a conflict over exclusive rights to bodies of water, especially exclusive economic zones (EEZs) as defined by the UN Convention on the Law of the Sea (UNCLOS). Apart from internal waters, however, states do not enjoy full sovereign rights in maritime areas under their jurisdiction, as they must permit vessels from other countries freedom of passage and transit. Maritime sovereignty thus is weaker than territorial sovereignty. As a result, maritime conflicts are less volatile than territorial disputes and, specifically, less likely to block or prevent cooperation among the United States, China, and Japan." ${ }^{19}$

Even so, as we shall see, such conflicts can inflame public passions, derail diplomatic relationships for years at a time, and cause governments to neglect the rational ordering of shortand long-term interests that is at the core of the neo-realist paradigm. Whether maritime disputes can be resolved may depend not only whether national identities can "accept neighboring countries as partners rather than threats and orient one's own country to trusting relations across civilizational boundaries," ${ }^{20}$ but also on such factors as a state's perception of its own domestic stability or the populist electoral strategies of particular political parties. Indeed, the global resurgence of nationalist populism during the decade of the 2010 s renders even more important an understanding of those forces that lead to the sidelining of neo-realist "national interest" calculation as a guide to policy.

This paper will examine the consequences of three of East Asia's outstanding maritime territorial disputes, those between Japan and Russia over the Northern Territories (the southern Kuril Islands of Kunashiri, Etorofu/lturup, Shikotan and Habomai), between Japan and South Korea over Dokdo/Takeshima, and between Japan and China over Diaoyu/Senkaku. It is not inconsequential that these conflicts involve Japan and the geopolitical detritus left behind by Japanese imperialism, which in each case (though perhaps in a slightly different way with the Kuriles) invokes the "history question." There are other significant commonalities between the

\footnotetext{
${ }_{18}$ M. Taylor Fravel, Strong Borders Secure Nation: Cooperation and Conflict in China's Territorial Disputes (Princeton: Princeton University Press, 2008), p.10.

${ }^{19}$ Fravel, "Explaining Stability in the Senkaku (Diaoyu) Islands Dispute" (note 12), p.146.

20 Gilbert Rozman, Northeast Asia's Stunted Regionalism: Bilateral Distrust in the Shadow of Globalization (Cambridge: Cambridge University Press, 2004), p.16.
} 
conflicts: all three have given rise to impassioned public protest within the contesting states; all have been the object of public grandstanding and bureaucratic intransigence on the part of political elites; all were impacted by the declarations that accompanied the end of World War II and the early Cold War; all have arguably become more intense as a result of the reconfiguration of East Asia's balance of power; and none - given the massive stakes involved in the relationships among the China, Japan, South Korea and Russia - would seem to warrant the role they have played in obstructing more constructive relationships between Tokyo on one hand and Beijing, Seoul and Moscow on the other. All three involve resources, both fishing interests and existing or potential natural gas and oil reserves.

Having noted the rancor invoked by these conflicts, it should also be acknowledged that the principal players have exercised restraint. ${ }^{21}$ Naval confrontation has not crossed the line to violence, though encounters between government patrol craft and civilian vessels over fishing rights have sometimes had an unhappy ending. The Japan-Korea dispute over Dokdo/Takeshima was restrained after 2010 by the joint response of both countries to North Korea's sinking of the South Korean naval vessel Cheonan and the DPRK's shelling of Yeonpyeong Island, though the rhetoric between Tokyo and Seoul later heated up again despite Pyongyang's dogged commitment to nuclear weapon and ballistic missile tests. Japanese posturing over the Northern Territories was dampened by the March 2011 Tohoku earthquake, tsunami and nuclear meltdown, as the triple disaster led to reduced reliance on nuclear power and increased dependency on gas and oil imports from Russia. Nonetheless, all three disputes have exacted a toll, sometimes significant, in the relationships between the disputants, and the point stressed below is that this toll has been disproportionate to what is at stake in the territorial conflict itself. Such "disproportion" contradicts at least part of the neo-realist understanding of interstate relations, despite the primacy given in neo-realism to state territoriality. We need to consider how alternative theories of international politics might explain this phenomenon, and what the high public profile of such disputes tells us about the neglected overlap between the domestic political environment and foreign policy-related concerns.

In what follows I will move from north to south, considering first the Kuriles dispute, then Dokdo/Takeshima, and finally Diaoyu/Senkaku.

\section{THE SOUTHERN KURILES/NORTHERN TERRITORIES DISPUTE ${ }^{22}$}

As imperial Russia advanced on the Far East region in the $18^{\text {th }}$ and $19^{\text {th }}$ centuries, encounters with the Japanese became more frequent, leading to negotiations to establish a border between the two countries. In the Treaty of Shimoda of 1855 , which marked the beginning of official

${ }^{21}$ See Fravel, "Explaining Stability in the Senkaku (Diaoyu) Islands Dispute" (note 12), passim.

22 See also Graeme P. Auton, “Japan, Russia and the Northern Territories Dispute: Reflections on an Evolving Northeast Asian Balance of Power," Japan Studies Association Journal, vol.9 (2012), pp.1-25; and Auton, "Japan and Russia: A Pivot Point?" Policy Forum. At: https://www.policyforum.net/japan-russia-pivot-point/. 
relations between Russia and Japan, the border was set in the middle of the Etorofu Strait, between Etorofu (Iturup) and Urup. ${ }^{23}$ However, this arrangement, which gave to Japan all of the four southern-most islands presently contested between Tokyo and Moscow to Japan, was in Japanese eyes fungible. Concerned about the lack of well-defined borders with Russia, the Meiji government in 1875 negotiated the Treaty of Saint Petersburg, which ceded all of Sakhalin Island to Russia in exchange for Japanese sovereignty over the entire Kuril Islands chain. For seventy years, until the end of World War II, all of the Kuril Islands - north to the channel separating Shumushu and the southern tip of the Kamchatka Peninsula - were part of Japanese territory. The Japanese-controlled northern Kuriles subsequently played a minor role in the 1904-05 Russo-Japanese War (a lingering source of historical animosity in both countries), and - still lodged in the Russian historical memory - served as a base for part of the allied intervention in the USSR, 1918-25, including the occupation of southern Kamchatka. It was at Hitokappu Bay, off Etorofu/lturup, that Admiral Chuichi Nagumo's carrier battle group assembled in late November 1941 to prepare for the attack on Pearl Harbor.

It is with the end of World War II that historical accounts become a matter of interpretation. As anticipated in the Yalta Agreement (February 1945) and the Potsdam Declaration (July 1945), the USSR entered the war against Japan on August 8, 1945. The Soviet military operation to occupy the Kuriles -

down to and including Kunashiri and the Habomai group - took place between August 18 and September 3, 1945 (the Japanese inhabitants of the islands were expelled two years later). In the eyes of Japanese it is significant that this military operation took place in its entirety after Emperor Hirohito's August $15^{\text {th }}$ radio address declaring Japan's surrender, and even continued after Foreign Minister Mamoru Shigemitsu signed the Instrument of Surrender on the battleship Missouri on September $2^{\text {nd }}$. Soviet actions in August and September 1945 continue to this day to be regarded as a "stab in the back" by most Japanese, who see the recovery of the four islands of the Northern Territories as "equated with righting a historic wrong and effacing a national humiliation." 24

\footnotetext{
23 The treaty also provided for shared Russian and Japanese administration of Sakhalin, essentially leaving its status open, which subsequently resulted in incidents between Russian and Japanese settlers.

${ }^{24}$ See John H. Miller, "Russia-Japan Relations: Prisoners of History," Asia-Pacific Center for Security Studies (Honolulu), October 2004, p.6.
} 


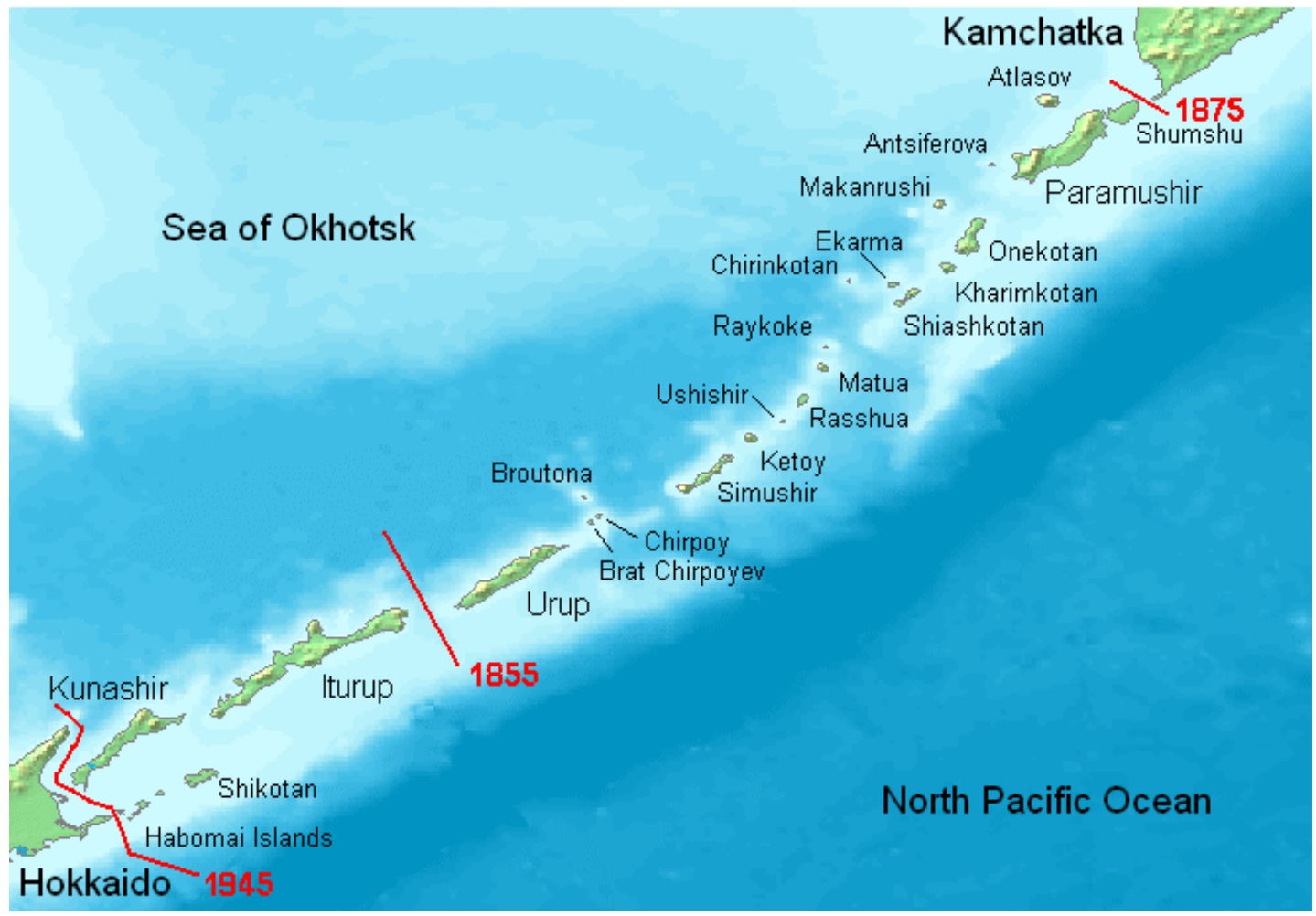

C)Japanfocus.org

At the time of the Yalta Agreement, the Roosevelt Administration's priorities had clearly been elsewhere, and the Agreement's vague declaration that "the Kuril Islands shall be handed over to the Soviet Union" passed largely unexamined until after the war ended, when the Truman Administration's commitment to Yalta's provisions began to fade. The February 11, 1945 Protocol of Proceedings of the Crimea Conference deals with the Kuriles in just eleven simple words: "The Kuril Islands shall be handed over to the Soviet Union." To this must be added the blunt language of the July 26, 1945 Potsdam Declaration: "Japanese sovereignty shall be limited to the islands of Honshu, Hokkaido, Kyushu, Skikoku and such minor islands as we determine." No specific determination was made that any of the four islands in the Northern Territories would be included in the area covered by Japanese sovereign authority. Article 2(c) of the San Francisco Peace Treaty of September 8, 1951 - signed by 48 governments, but not the USSR ${ }^{25}$ - stated that "Japan renounces all right, title and claim to the Kuril Islands, and to that portion of Sakhalin and the islands adjacent to it over which Japan acquired sovereignty as a consequence of the Treaty of Portsmouth of 5 September 1905 [ending the Russo-Japanese War]."

\footnotetext{
25 Soviet opposition to the San Francisco Treaty was based on a number of factors: that the People's Republic of China, as a victim of Japanese aggression, was not invited to participate; that the treaty provided inadequate guarantees against the re-emergence of Japanese militarism; that the USSR was not properly consulted as the treaty was being drafted; that the treaty set up Japan as a component of a military coalition of states headed by the U.S.; and that the treaty, in violation of the Yalta understandings, did not explicitly recognize Soviet sovereignty over southern Sakhalin and the Kuril Islands. It should be noted too, of course, that the treaty was signed in the very middle of the Korean War, in which the U.S., South Korea and their United Nations coalition partners were in a bitter and costly struggle with the Peoples Republic of China, North Korea, and - indirectly - the Soviet ally of China and the DPRK.
} 
The intensification of East-West conflict during the Cold War brought about a change in Washington's position on the Kuriles. The U.S. State Department somewhat disingenuously began to declare that Habomai and Shikotan were historically part of Hokkaido, and therefore not included in post-World War II arrangements. ${ }^{26}$ The U.S. government argued that "the precise definition of the extent of the Kuril Islands" should be a matter of bilateral negotiation between Japan and the USSR, which had yet to conclude a peace treaty with each other. ${ }^{27} \mathrm{~A}$ technical state of war existed between Japan and the USSR until the Japan-Soviet Joint Declaration of October 19, 1956, which ended the state of war and facilitated the establishment of diplomatic relations, but did not constitute a peace treaty. In August 1955 Moscow had announced that it would consider returning two of the islands, the Habomai group and Shikotan, as part of a completed peace agreement, but this was rejected out of hand by Japanese Foreign Minister Mamoru Shigemitsu, who - in an early indication of Japanese intransigence - stated that an agreement had to involve all four islands or nothing. ${ }^{28}$

From that point forward, and throughout the Cold War, the Northern Territories issue hamstrung relations between Tokyo and Moscow as the two adversaries confronted each other across the 8.5 mile $(13.7 \mathrm{~km}$.) wide Nemuro Strait between Hokkaido and Kunashiri. The Japanese government did not significantly participate in East-West détente and was slow to respond to the dramatic changes under Gorbachev - largely because of the territorial issue. Despite Japan's continuing claim in subsequent decades that the four islands of the Northern Territories were historically Japanese and not part of the Kuriles, and despite Moscow's 1960 announcement that the 1956 agreement was "not in effect" because of the Japan-U.S. security treaty, the Joint Declaration and the August 1955 "two islands" formula it potentially embraced would eventually under Vladimir Putin - be asserted by the Russians to be the only legal basis for further discussions.

\footnotetext{
26 See Bruce A. Elleman, Michael R. Nichols, and Matthew J. Ouimet, "A Historical Reevaluation of America's Role in the Kuril Islands Dispute," Pacific Affairs, vol.71, no.4 (Winter 1998-99), pp.489-504.

27 Ibid.

${ }^{28}$ When Shigemitsu finally relented in 1956, the deal was killed by U.S. Secretary of State John Foster Dulles, who argued that Japan did not have the authority to permanently transfer sovereignty over two of the islands (Kunashiri and Etorofu/lturup) to the Soviet Union.
} 


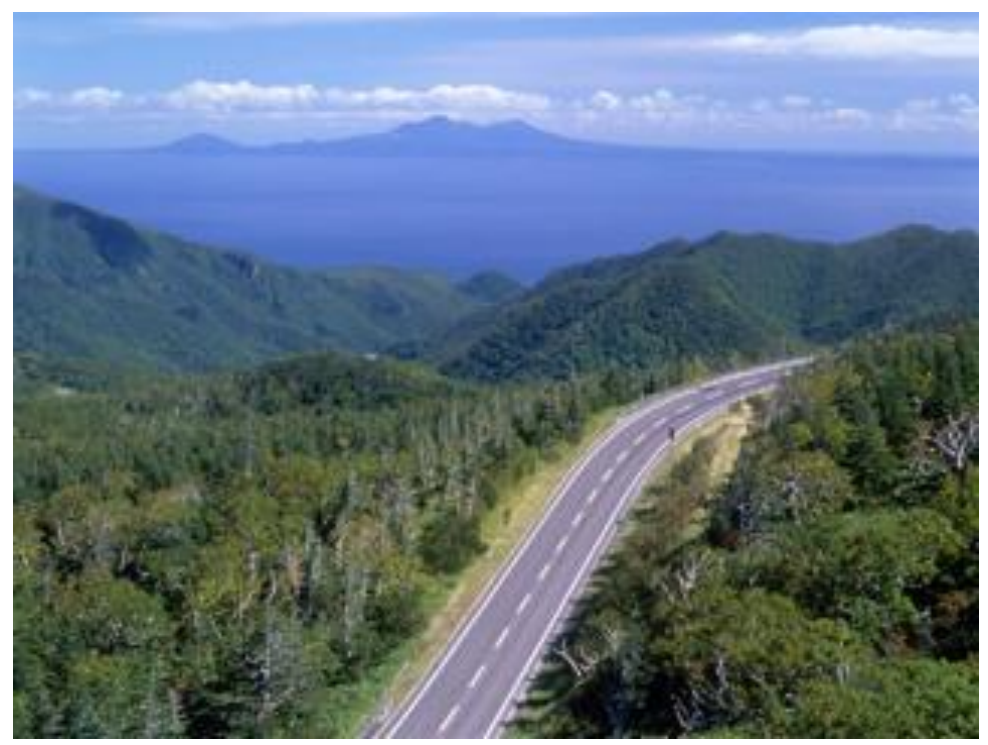

Above: Kunashiri Island as seen from Hokkaido

The Japanese public's dislike and distrust of 'Soviet Russia' survived both the decline of the Japanese left in the 1970s and the eventual collapse of the USSR. Such sentiments were not restricted to the conservative elite. "The Soviet Union consistently topped the list of "least liked countries' in opinion polls ... [This] also reflected memories and myths about Russian behavior, which had pre-Cold War roots. These negative associations persisted even after the demise of the Soviet Union and the emergence of 'democratic Russia,' casting a pall over Russo-Japanese relations to the present." 29 The intransigence of negative Japanese public perceptions of Russia, even after the collapse of the USSR, is a textbook case of the persistence of identities (and interests growing from those identities) to which constructivist international relations theorists have frequently referred. ${ }^{30}$ This intransigence, often reflected in the statements of Japanese politicians and elements of the Foreign Ministry, became more entrenched after the rise to power of Vladimir Putin in Russia in 2000 and Junichiro Koizumi in Japan in 2001. Putin and Koizumi both foreshadowed the wave of nationalist populism that would begin to sweep the planet a decade later.

Earlier, in the late 1990s, there had been a brief window of opportunity during which some resolution of the Northern Territories dispute might have occurred. Between 1996 and 2000, after earlier fits and starts with the Yeltsin government, Prime Ministers Ryutaro Hashimoto, Keizo Obuchi and Yoshiro Mori sought to fashion a qualitatively different relationship with Russia that might lead to a formal peace treaty and some movement on the territorial issue. In three meetings between Yeltsin and Hashimoto, ${ }^{31}$ one between Yeltsin and Obuchi, ${ }^{32}$ and two between

\footnotetext{
${ }^{29}$ Miller, "Russia-Japan Relations: Prisoners of History?" p.7.

30 See footnote 1.

31 The Denver G-7 summit, June 1997; Krasnoyarsk, November 1997; Kawana, April 1998.

32 Moscow, November 1998.
} 
Mori and Putin ${ }^{33}$ the two sides explored different formulas for either a "two islands" solution or a "special legal regime" for all four islands. For a brief period, the Japanese government's strategy was to embed the territorial issue in the broader tapestry of the multi-dimensional RussoJapanese relationship, and (in the 1990s) an economically battered Russia was willing to reciprocate. ${ }^{34}$ By 1999, "Japanese decision-makers had begun to think pragmatically about Russia in light of the evolving strategic situation in Northeast Asia. There was a confluence of thinking with Russia, as both responded to the rise of China while also striving to maintain good relations with Beijing." ${ }^{35}$

This was short-lived. By the beginning of the new decade it was clear that Hashimoto, Obuchi and Mori had pushed Russia policy beyond what was sustainable in the crucible of Japanese public opinion and Tokyo's leadership politics. During 2000 a fratricidal struggle between liberal and conservative elements in the Japanese Foreign Ministry resulted in a victory for hard-liners, and rejection by the ruling Liberal Democratic Party (LDP) of a "gradualist" approach in which a territorial settlement might be part of a Russo-Japanese peace treaty. ${ }^{36}$ Koizumi, as Prime Minister between April 2001 and September 2006, returned to the "all or nothing" policy on the four islands. Meanwhile, the rise to power in Russia of Vladimir Putin, willing to use his United Russia Party to incite nationalist sentiment, combined with Russia's changed economic fortunes as energy prices climbed, meant decreased odds of compromise emanating from Moscow. Russo-Japanese colloquy over the islands reached a new intensity following Russian President Medvedev's four-hour visit to Kunashiri on November 1, 2010, following Japanese Foreign Ministry warnings that he must not go - leading to the recall of Japanese ambassador Masaharu Kono from Moscow. ${ }^{37}$ In 2015 Medvedev visited the Kuriles yet again, declaring - lest the Japanese had not received a clear message - that the islands are "an important region of our country." 38

Even before the fall 2010 crisis, public sentiment in Japan and Russia had hardened as a result of the drift toward populist nationalism in both countries. According to a July 2009 poll conducted by the All-Russian Public Opinion Research Center (VTsIOM), 89\% of respondents were against territorial concessions to Japan in the Kuril Islands dispute, compared to $76 \%$ from a similar poll

\footnotetext{
33 St. Petersburg, May 2000; Irkutsk, March 2001.

34 The Denver G-7 summit, June 1997; Krasnoyarsk, November 1997; Kawana, April 1998.

${ }^{34}$ Moscow, November 1998.

${ }^{34}$ See Joseph P. Ferguson, "Japanese Strategic Thought toward Russia," in Gilbert Rozman, Kazuhiko Togo and Joseph P. Ferguson, eds., Japanese Strategic Thought toward Asia (New York: Palgrave Macmillan, 2007); and Alexander Panov, "The Policy of Russia toward Japan 1992-2005," in Gilbert Rozman, Kazuhiko Togo and Joseph P. Ferguson, eds., Russian Strategic Thought toward Asia (New York: Palgrave Macmillan, 2006). Notes Panov, "On the whole, the approach set forth assumed that the search for a way out in resolving the most complicated - territorial problem was through the all-around development of Japanese-Russian ties . .." (p.175).

${ }_{35}$ Ferguson, Japanese Strategic Thought toward Russia," p.211.

36 See ibid., pp.211-12.

37 “Japan Recalls Envoy to Russia over Kuril Islands Dispute," New York Times, November 2, 2010.

38 See Luibomir K. Topaloff, "How Putin Outplayed Abe in Japan," The Diplomat, December 23, 2016. At: https://thediplomat.com/2016/how-putin-outplayed-abe-in-japan/.
} 
in 1994. ${ }^{39}$ Both Medvedev and Putin were more than willing to exploit such passions in Russia's 2012 election. As Moscow commentator Dmitri Trenin noted, "while once only Japanese politicians used the island issue to pursue their domestic political objectives," now Russia's leadership was willing to do the same. ${ }^{40}$ Russians, increasingly regretful of the dissolution of the Soviet Union and forced to endure two Chechen wars and a string of associated terrorist atrocities in order to preserve their territorial integrity, were not sympathetic to the idea of voluntarily surrendering territory to a historical adversary. In Japan, meanwhile, a consortium of activist organizations mobilized public opinion to support the return of the Northern Territories to Tokyo's jurisdiction, and on June 11, 2010 - designated as Northern Territory Day - the Diet passed a resolution reasserting Japan's sovereignty over the four islands. Various private groups have in subsequent years cooperated with local and national government to campaign for the return of the islands as part of a broader Northern Territories reversion movement. ${ }^{41}$

With the end of the Cold War and the collapse of the Soviet Union, the imperative of Japanese rapprochement with Russia was driven by four factors: (1) increasing strategic ambiguity on the part of the U.S., accompanied by America's declining relative power, its political-military drawdown in East Asia, and - with both Obama and Trump - the growing unpredictability of Washington's outlook; (2) the rise of China as an economic, political and military giant, a regional bully, ${ }^{42}$ and a significant counterweight to Japanese influence; (3) the emergence of new regional threats and instabilities, particularly the nuclear and ballistic missile threat posed by an unpredictable North Korea; and (4) the real possibility of a marriage between Japanese capital and technology, on one hand, and Russia's abundant resources on the other, particularly in the area of energy extraction. From post-Soviet Russia's perspective, a further factor could be added: the need to stabilize and develop a Russian Far East that was losing population and increasingly prone to gangsterism and assertions of autonomy from Moscow. As during the Cold War, all of these interests - in the Japanese Foreign Ministry and in the Kremlin - were subordinated to the territorial conflict over four small islands.

With these interests in mind, President Putin and Japanese Prime Minister Shinzo Abe met on the margins of the Pacific Rim summit in Lima in November 2016, and again for a bilateral summit in Tokyo on December 16, 2016. They discussed "joint economic activity, energy exploitation, and the marriage of Russia's abundant natural resources with Japanese capital, but earlier Japanese expectations of a breakthrough on the Northern Territories and a peace treaty proved unrealistic. $^{43}$ At the end of a two-day meeting, Abe did not get his islands and Putin did not fly

\footnotetext{
39 See Russian Public Opinion Research Center, Press Release No.1327, August 12, 2010.

40 Dmitri Trenin, "Russia-Japan: Politics vs. Strategy," Carnegie Moscow Center, November 3, 2010.

41 These organizations include the Northern Territories Issue Countermeasures Association, the Japan League for the Return of the Northern Territories, the League of Chishima Habomai Islands Residents (reputed to have a budget of 187 million Yen, \&1.7 million US, in 2008), and the Hokkaido Committee to Promote Exchanges with Four Northern Islands. See www.koueki.jp/disclosure/chishima-habomai/0.pdf.

42 See Auslin, End of the Asian Century, pp.145-149.

${ }^{43}$ See Topaloff, "How Putin Outplayed Abe in Japan (note 37)," passim.
} 
back to Moscow with the promise of multi-billion-dollar Japanese bank loans, though there was agreement (vague, to be sure) on joint contributions to economic development in the southern Kuriles. The two met again on May 26, 2018, following the St. Petersburg International Economic Forum, but - as before - progress was elusive.

In both Japan and Russia, nationalism, public opinion, bureaucratic timidity and historical memory have effectively overshadowed realist calculation of national priorities and the rank ordering of state interests. The Northern Territories do have conventional geopolitical and economic significance, to be sure. The Kuriles seal off the Sea of Okhotsk, turning it into Russia's private sea and a safe bastion for Moscow's nuclear submarines, and the islands possess rare minerals - including gold and rhenium, a material used in the turbine blades and exhaust nozzles of jet engines. There is also the promise of so-far-unexploited gas and oil reserves. ${ }^{44}$ But these assets, particularly in view of the fact that the dispute involves only the four southern-most islands, hardly outweigh the enormous potential gains to both countries from a normalized, cooperative relationship. A peace treaty embracing the islands would have enormous symbolic and political importance for the Abe government. But it might also be important to Putin, reinforcing Moscow's global legitimacy, and supporting the effort of both Russia and China to pull Japan away from its hard alignment with the United States (at this point not likely, given that even today - "Japanese public attitudes against Russia are ranked among the most critical in the world.") ${ }^{45}$

\section{THE DOKDO/TAKESHIMA (LIANCOURT ROCKS) DISPUTE}

Although the Dokdo/Takeshima dispute has deep historical roots, its recent salience owes a great deal to the decline of U.S. influence and the reconfiguration of Northeast Asia's balance of power. U.S. influence eroded in the region during the George W. Bush administration, as Washington became preoccupied by commitments in the Middle East and Southwest Asia, and Tokyo and Seoul both felt the need to assert their interests more independently, in part through appeals to nationalism. U.S. President Obama's ineffectual "pivot" to Asia did little to arrest this trend. The combination of China's rise, American neglect, and more strident nationalism in the domestic politics of both Japan and South Korea has made it more difficult for the U.S. to continue to broker the "virtual" alliance between Tokyo and Seoul. Japan and South Korea are both formally allied to the U.S., but not each other, and Washington - in its effort to construct a more solid relationship between its two Northeast Asian partners - is now running into the limitations of the logic of "the enemy of my enemy (e.g, North Korea) must be my friend."

Japanese assertiveness over Dokdo/Takeshima beginning in 2005 was partly grounded in the Koizumi government's fanning of nationalist sentiment, and more recently in the Liberal Democratic Party's (LDP's) decision to move toward remilitarization in the face of China's rise,

\footnotetext{
${ }^{44}$ See ibid,

45 lbid.
} 
North Korea's provocations, and incipient doubts about the reliability of Washington's military protection. ${ }^{46}$ The LDP's newfound firmness on territorial and security issues was clearly reflected in the Shinzo Abe government's success in pushing its collective self-defense law through the Diet in July and September 2015, which modified Article 9 of the Constitution to permit Japan a normal "collective defense" relationship with the United States. ${ }^{47}$
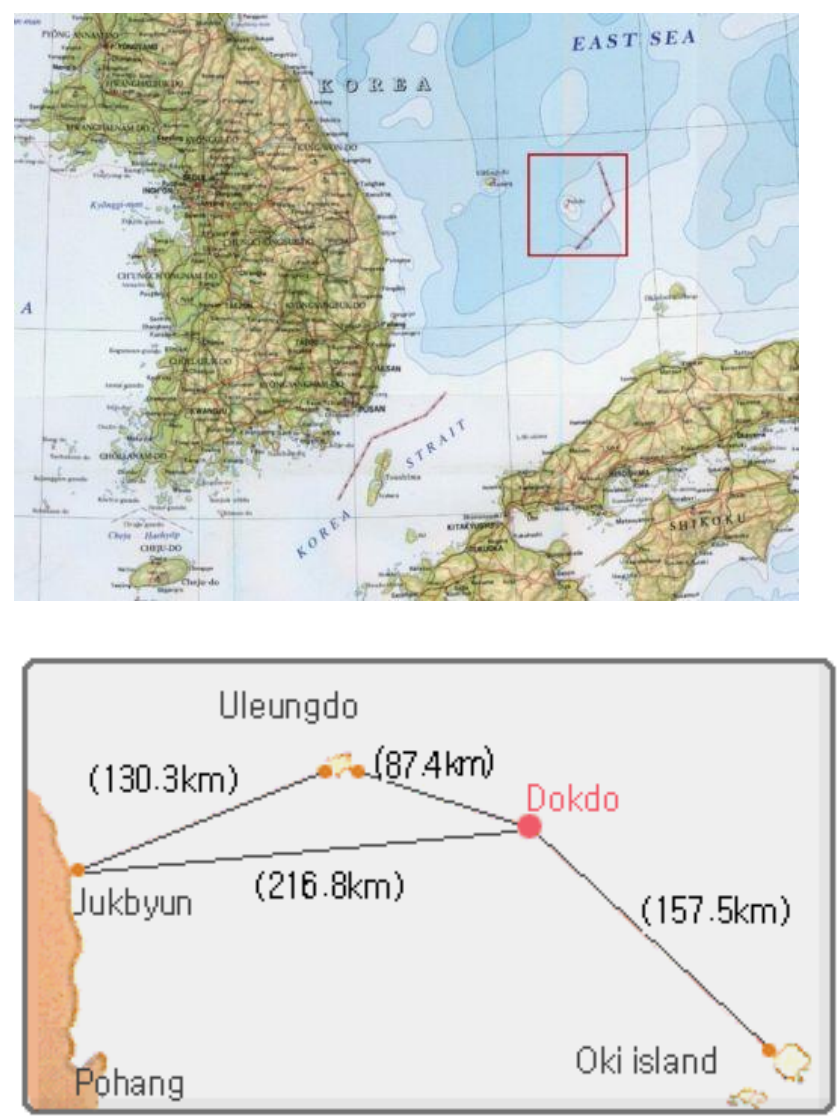

It has been feared that if Tokyo backs down on Dokdo/Takeshima, Japan will lose traction in its territorial disputes with Moscow and Beijing. As Ralf Emmers has put it, "should Japan lose its claim to the islets, the similar claims made to the Northern Territories/Kuriles and the Senkaku/Diaoyu Islands . . may also be undermined. As all these disputes derive from a similar interpretation of the San Francisco Peace Treaty [of 1951], Japan would, by renouncing claims over the Tokdo/Takeshima Islands, weaken its position with regard to the others." ${ }^{48}$ Clearly, little

\footnotetext{
${ }^{46}$ On the evolution of Japan's foreign and security policy debate, see Richard J. Samuels, Securing Japan: Tokyo's Grand Strategy and the Future of East Asia (Ithaca: Cornell University Press, 2007); Christopher H. Hughes, Japan's Remilitarisation (London: International Institute for Strategic Studies, 2009); Kent E. Calder, Pacific Alliance: Reviving U.S.-Japan Relations (New Haven: Yale University Press, 2009); and Tomohito Shinoda, Koizumi Diplomacy: Japan's Kantei Approach to Foreign and Defense Affairs (Seattle: University of Washington Press, 2007).

47 See Reiji Yoshida \& Mizuho Aoki, "Diet Enacts Security Laws, Marking Japan's Departure from Pacificsm," The Japan Times, September 19, 2015. At: https://japantimes.co.jp/.../diet-enacts-security-laws-marking-japans ... . 48 Ralf Emmers, Japan-Korea Relations and the Tokdo/Takeshima Dispute: The Interplay of Nationalism and Natural Resources, RSIS Working Paper No.212 (Singapore: S. Rajaratnam School of International Studies, 10 November 2010), pp.12-13.
} 
was achieved by the Obama administration's reassertion of an American security presence in East Asia following the 2010 Cheonan and Yeonpyeong Island incidents, and the U.S. failed to arrest a more aggressive trend in Japanese foreign policy, a trend now actively supported by the administration of Donald Trump. It remains to be seen whether Trump's policies can reach a better result, given the steady rise of China's capabilities, North Korea's "maturation" as a nuclear power, and Russia's decision since the mid-2000s to take a more active role in the Asia-Pacific region.

For South Koreans, Dokdo is more than a matter of territory and security. It is also a matter of historical sensitivities and nationalist symbolism. Tokyo's claim to the islands dates to 1905, the year in which Japan's imperial subjugation of all of Korea began, and its present assertiveness over them is tied in Koreans' minds to the rekindling of Japanese historical blindness and lack of contrition about past misdeeds. As South Korea's Secretary for Public Information, Baek-man Lee, emotionally put it in 2006: "Exactly 100 years after its occupation of Korea, Japan is again attempting to rob us of our history. The key to the Dokdo issue is the liquidation of the war of the Japanese imperialists' aggression. In that sense, Dokdo stands at the center of our efforts to rectify a history distorted by a war of aggression." ${ }^{4}$ Displaying the rhetorical over-reach for which he was sometimes known, South Korean President Roh Moo-hyun, in an April 25, 2005 speech, accused Tokyo through the Dokdo issue of denying South Korea's "full liberation and independence," called upon Japanese to repent for their colonial past, and charged that Japan was a greater threat to regional stability than either Beijing or Pyongyang. ${ }^{50}$ Roh's comment was in part a response to the March 2005 decision of Japan's Shimane Prefecture to designate February $22^{\text {nd }}$ as "Takeshima Day," a move consistent with Japan's growing nationalism at a time when the Koizumi government was actively engaging in such provocations as Prime Ministerial visits to the Yasukuni Shrine.

In South Korea, the subsequent Grand National Party (GNP) government of Lee Myung Bak and besieged Saenuri Party government of Park Guen Hye were less likely than Roh Moo-hyun's Democrats to "tilt" toward either Beijing or Pyongyang, and in fact made some effort to improve ties with Japan. ${ }^{51}$ Still, in 2008 , South Korea temporarily recalled its ambassador to Tokyo over the depiction of the Dokdo dispute in Japanese middle school textbooks, there were protests at the Japanese embassy in Seoul, and the Korean Defense Ministry sent marines to the islands. The return to power of the Democrats (Minjoo Party) under Moon Jae-in in 2017 changed the calculus yet again. In November 2016 the conservative Park Geun-hye government of South Korea had concluded a military intelligence sharing agreement with Japan, the General Security of Military Information Agreement (GSOMIA), which would have allowed Seoul to take advantage

\footnotetext{
${ }^{49}$ Quoted in Michael Weinstein, "South Korea-Japan Dokdo/Takeshima Dispute: Toward Confrontation," Power and Interest News Report (PINR) and Japan Focus, May 10, 2006, p.4.

50 lbid., pp.5, 6.

51 See East Asia Institute, On the Rocks: Korea and Japan Divided over the Dokdo Issue, EAI Commentary No.11 (Seoul: East Asia Institute, 10 August 2010), p.2.
} 
of Japan's vastly superior technical intelligence collection assets. ${ }^{52}$ One year later, the newly elected left-wing (but nonetheless nationalist) Moon government rejected GSOMIA, and limited its intelligence sharing with Japan to analysis of North Korea's nuclear and ballistic missile tests. ${ }^{53}$ At play was an array of historical issues, including Japan's role as a colonial occupier between 1910 and 1945, Korean "comfort women" during World War II, and Japan's avoidance of history in public school textbooks. High on the list of South Korean grievances, though, was Dokdo/Takeshima. In a March 1, 2018 speech Moon reminded Koreans that the seizure of Dokdo was the first step toward Japan's 1910-45 colonialism and argued that Tokyo's continued territorial claim "was nothing more than a rejection of any reflection of Japan's imperialist invasion." 54 At both the 2018 Winter Olympics and the April 27, 2018 Panmunjom summit between Moon and North Korean leader Kim Jong Un there were reminders that antipathy to Japan over Dokdo is a sentiment shared by North and South Korea. The Moon government has distanced itself from U.S.-Japan-South Korea trilateralism, made it clear that the relationship with Japan will not turn into a military alliance, and indicated its intention to work more closely with China. ${ }^{55}$ Sentiments in Japan have hardly been less forgiving: On January 25, 2018, the National Museum of Territory and Sovereignty opened in Hibiya Park in downtown Tokyo, replete with displays related to both Dokdo/Takeshima and Diaoyu/Senkaku. Dokdo/Takeshima has been fully incorporated into the Japanese national consciousness as well.

To nationalist/populist and geostrategic issues must be added the issue of resources, reinforced by the U.N. Convention on Law of the Sea (UNCLOS) provision for 200 nautical mile exclusive economic zones (EEZs), which accord their possessor exclusive right to fisheries and seabed exploration. The discovery of natural gas hydrates (estimated at 600 million tons) in the East Sea/Sea of Japan seabed set Seoul and Tokyo on a collision course over surveying the seafloor and naming its features. ${ }^{56}$ A 1999 agreement did not demarcate Japanese and South Korean EEZ boundaries, but it did give fishing rights around Dokdo/Takeshima to both Japan and Korea, while leaving unresolved the question of seabed exploitation. ${ }^{57}$ Subsequently, Japan's spring 2006 decision to send survey vessels to the waters around the islands triggered Seoul's dispatch of twenty gunboats to block them, leading to a diplomatic stand-down only after intense discussions that were mindful of public passions on both sides.

\footnotetext{
52 Japan operates five surveillance satellites, four land-based radar installations with a range more than 1,000 km., 77 maritime patrol aircraft, and six Aegis-equipped destroyers.

53 See Yeo Jun-suk, "South Korea Refuses to Share Military Intelligence with Japan: Report," The Korea Herald, November 20, 2017. Also "Friends or 'Frenemies?' South Korea Fails to Meet Obligations of Military Intelligence Sharing Deal with Japan," South China Morning Post, November 20, 2017.

${ }^{54}$ Hajimu Takeda, "Moon Lashes Out at Japan Stance on Issues from the Colonial Era," Asahi Shimbun, April 1, 2018 (www.asahi.com).

$55 \mathrm{lbid}$.

56 "The Korea Gas Corporation projects that the amount of methane hydrate deposits to be found in the surrounding seabed would be capable of fulfilling South Korean demand for natural gas for 30 years." Emmers, Japan-South Korea Relations and the Tokdo/Takeshima Dispute, p.15.

57 lbid., p.16.
} 


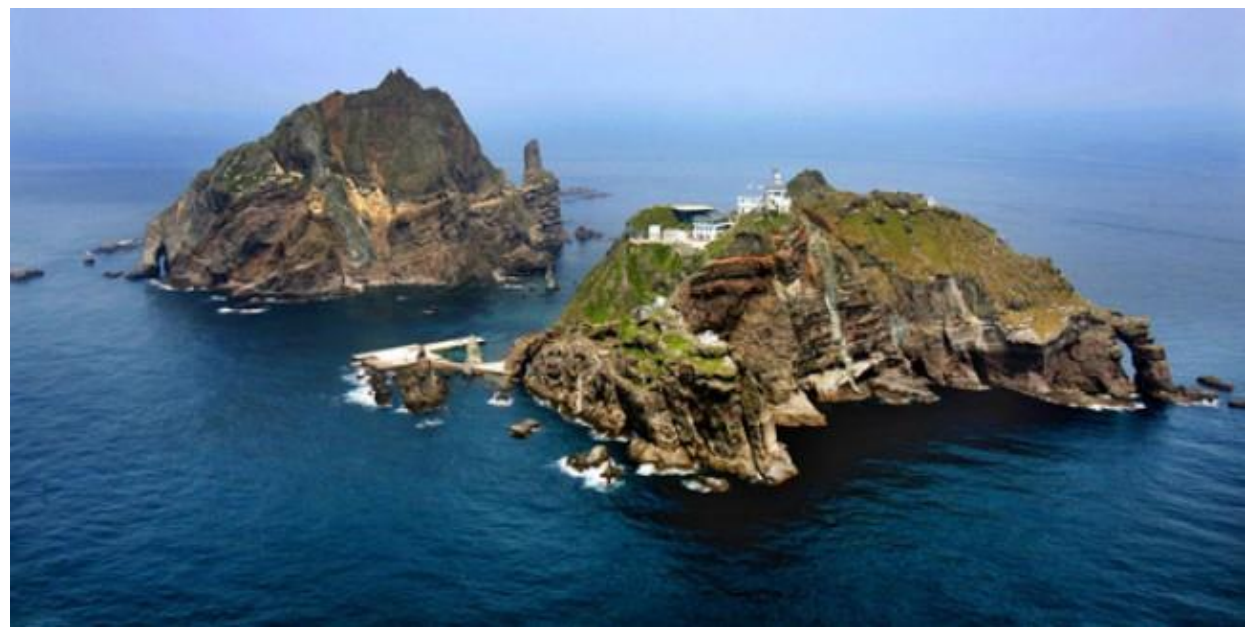

Above: Dokdo/Takeshima

Dokdo has achieved a salience in the South Korean public mind comparable with "comfort women," the Yasukuni Shrine and other vestiges of Japan's imperial past. Meanwhile, Tokyo has continued to take the position - as it has since the 1950s - that the territorial issue should be settled at the International Court of Justice (ICJ) in The Hague, a position that is easy for it since Korea is in actual possession of the islands and Japan has nothing to lose by submitting to international arbitration. Seoul, for its part, has asserted that Dokdo is simply a part of Korea, and that there is no justiciable issue for the ICJ to consider. History, the South Koreans argue, is completely on their side.

Yet, as Ralf Emmers has noted, the history of the Dokdo/Takeshima dispute is complicated by the arcane and indeterminate documentation invoked by both parties. ${ }^{58}$ Korean claims go back to 512 AD and the Silla Kingdom, as indicated by the Samguk-Sagi (Chronicles of the Three Kingdoms), Korea's oldest history published in $1145 .{ }^{59}$ Koreans also argue that Korean control of the islands was recognized in 1696, when the Tokugawa Shogunate banned Japanese fishing in the area, and again in 1877 when the Japanese Supreme Council (Daijo-kan) issued an order stating that Uleungdo (Matsushima to the Japanese) and "another island" were not under Japanese rule, the "other island" being Dokdo. ${ }^{60}$ Such arguments are supported by maps from the period. Japan, on the other hand, originally contended that Dokdo/Senkaku was unoccupied (terra nullius) prior to the Japanese Cabinet's imperial decree of January 28, 1905 annexing the islands as a consequence of the armed conflict with Russia, though that claim was later changed

\footnotetext{
58 lbid., pp.8-9.

59 See I. Uwe, "An Island Dispute with a Past," Yomiuri Shimbun, March 20, 2005.

60 Ibid., p.8. Also, "A Study of Korea's Territorial Rights to Tokdo (Liancourt Rocks) and the Japanese Invasion," of Korean Independence Movement Studies, vol.3 (November 1989).
} 
to one of "effective occupation."61 Koreans have argued that both of these claims were inconsistent with Japan's prior recognition of the islands as Korean territory. One thing is certain: Japan's 1905 incorporation of Dokdo/Takeshima, like its ground and naval operations against the Russian Empire, served as a precursor to Japanese declaration of a protectorate over Korea later the same year, and to colonial subjugation of the Korean Peninsula between 1910 and 1945.

As with the Kuril Islands dispute, post-World War II documentation regarding the fate of Dokdo is dogged by sloppiness and imprecision, as well as by a shifting U.S. position as the Cold War became more deeply entrenched. The July 26, 1945 Potsdam Declaration was straight-forward in its simplicity: "Japanese sovereignty shall be limited to the islands of Honshu, Hokkaido, Kyushu, Shikoku and such minor islands as we determine." As with the Kuriles, Dokdo/Takeshima was not at the time determined to be under Japanese sovereignty. Earlier drafts of the San Francisco peace treaty, until November 1949, incorporated a U.S. proposal that the islands should be returned to Korean control. ${ }^{62}$ After that, as a consequence of the Korean War, Washington's mounting concern about the Cold War confrontation in Asia, and its growing need for Japan's material support in the Korean conflict, the U.S. position changed. ${ }^{63}$ On August 10, 1951 thenU.S. Assistant Secretary of State Dean Rusk communicated to South Korean Ambassador Yang You Chan that ". . . the island of Dokdo, otherwise known as Takeshima or Liancourt Rocks, [was] never treated as part of Korea and, since about 1905, has been under the jurisdiction of . . . Shimane Prefecture, Japan. The island does not appear ever before to have been claimed by Korea." ${ }^{4}$ Rusk's comment was probably, more than anything, a reflection of (1) American ignorance of the situation and (2) increasing U.S. fears about the conduct of the Korean War. By the time the actual San Francisco Treaty was signed, on September 8, 1951, the issue of Dokdo/Takeshima was left off the agenda altogether, and the U.S. has subsequently refused to take a position. As Michael Weinstein observed in 2006, "Washington has remained neutral, urging both sides to reach an amicable resolution to their dispute. That position is thrust upon Washington because a tilt toward Tokyo would drive Seoul closer to the arms of Beijing and Pyongyang, and a tilt toward Seoul would impel Tokyo to assert its independence more forthrightly." 65

\footnotetext{
${ }^{61}$ See Sean Fern, "Tokdo or Takeshima? The International Law of Territorial Acquisition in the Japan-Korea Island Dispute," Stanford Journal of East Asian Affairs, 5:1 (2005).

62 See Emmers, Japan-Korea Relations and the Tokdo/Takeshima Dispute, p.9.

63 This was consistent with the U.S. change of position on the Kuriles issue. Confronted with the stresses of the EastWest confrontation and the Korean War, Washington decided to throw all of its eggs into the Japanese basket. This was true both of the southern Kuriles ("which should have been considered part of Hokkaido) and of Dokdo/Takeshima. Washington subsequently backed down in the case of Dokdo/Takeshima, but did not do so with the southern Kuriles. As late as May $30^{\text {th }}$ 2011, the Russian Foreign Ministry summoned U.S. Ambassador to Moscow, John Beyrle, to communicate the Medvedev government's unhappiness over U.S. statements supporting Japan's claims to the four islands in the Northern Territories. The U.S. has chosen to be more circumspect in its approach to a highly emotional issue separating two allies.

${ }^{64}$ Moteki Hiromichi, "Takeshima (Dokdo) Island is Japanese Territory, No Matter the Upheaval of Heaven and Earth." Hiromichi provides a facsimile of the Rusk communication.

65 Weinstein, "South Korea-Japan Dokdo/Takeshima Dispute," pp.6-7.
} 
Violent North Korean provocations in 2010 and subsequent DPRK threats during U.S.-South Korean joint military exercises (which reached new intensity in the period 2013-15) have reminded South Korea and Japan of the continued importance of their security ties to Washington and of their "virtual" alliance with each other (each is allied to the U.S., even though there is no formal alliance between them). Economically, South Korea and Japan have become more intertwined - in terms of trade and investment - than ever before, though Japan is now constantly looking over its shoulder at the trade, investment and technological challenge mounted by the South Koreans. China-Japan-South Korea cooperation, evidenced in several trilateral summits, has signaled a greater willingness to cooperate on both regional and global issues. Yet posturing over Dokdo/Takeshima has continued, in part because Japan has backed itself into a corner (it cannot make concessions on Dokdo without setting a precedent relevant to both the Kuriles and Diaoyu/Senkaku), but also because the islands have become an object of virulent nationalism on both sides, and because of the future (if yet undefined) prospect of energy resources. $^{66}$ Japan and South Korea are both democracies, and it is particularly difficult for a democratic government to make concessions on a territorial issue that has taken on public traction, since concessions may lead to electoral defeat. Indeed, it is precisely for this reason that democratic states are more likely to follow "delaying and avoidance" strategies in territorial conflicts, rather than pursuing either negotiated cooperation or escalation. ${ }^{67}$

\section{THE DAOIYU/SENKAKU DISPUTE}

As with the Dokdo/Takeshima confrontation, the growing virulence of the Sino-Japanese confrontation over the Daoiyu (in Chinese) or Senkaku (in Japanese) islets is a consequence of both declining U.S. power in the region and the increasing strength of East Asian nationalism. Of the three island disputes discussed here it is clearly the most dangerous, invoking a clear prospect of military conflict between China and Japan. In this respect, the Daoiyu/Senkaku confrontation is not unlike that over the Paracel and Spratly Islands in the South China Sea, which also has the potential to escalate into military conflict between China, its regional neighbors, and possibly the United States. Tokyo claims that "China did not protest the Japanese annexation - and ignored the Japanese incorporation of the Senkaku Islands into Okinawa prefecture" - until 1968, when a U.N. Economic Commission for Asia and the Far East (ECAFE) survey found "prolific" oil and natural gas reserves on the continental shelf between China and Japan's Ryukyu Island chain. ${ }^{68}$ In Tokyo's view, then, the disputed claim to Daoiyu/Senkaku (both the 12-nautical mile territorial sea and the outlying 23-nautical mile "contiguous zone") is primarily based on economic and resource interests. However, as I will argue here, Monika Chansoria is more probably correct when she states that:

\footnotetext{
${ }^{66}$ See East Asia Institute, On the Rocks: Korea and Japan Divided over the Dokdo Issue.

67 See Fravel, Strong Borders Secure Nation, pp.10-39.

68 Sasakawa Peace Foundation USA, Senkaku Islands Tabletop Exercise Report (Suffolk, Virginia: Lockheed Martin Center for Innovation), March 28-30, 2017, p.2.
} 
"Chinese domestic politics, including pressure on the central government to craft a strong Chinese national identity, is among the main drivers behind China's provocations. The Party and the government in China repeatedly have demonstrated a penchant for flashing the 'Japan card' to consolidate its control internally and crush any potential form of challenge that might destabilize China domestically."69

In Chansoria's view the primary factor underpinning the dispute is nationalism, and - on Beijing's side - the ability of the PRC to invoke nationalism as a source of domestic political stability.

China claims that the Ming Dynasty (1368-1644) considered Diaoyu/Senkaku part of its maritime territory, and that the Qing Dynasty (1644-1911) placed the islands under the jurisdiction of Taiwan (part of the Qing Dynasty until 1895). Japan assumed administration of the islands in 1895, late in the Sino-Japanese War, when the Imperial Japanese cabinet decided to annex them to Okinawa prefecture, claiming they were uninhabited and therefore fell to Japanese sovereignty under the international legal doctrine of terra nullius. Although the islands lie just 170 kilometers from Taiwan, Japan's claim was independent of its assumption of sovereignty over Taiwan (Formosa) following its brief war with China. A Japanese fish processing plant operated on the largest island for several decades, but was abandoned at the beginning of World War II. The legal picture became more confused following Japan's defeat in the second world war, at which time control of the islands passed to the United States as part of the occupation.

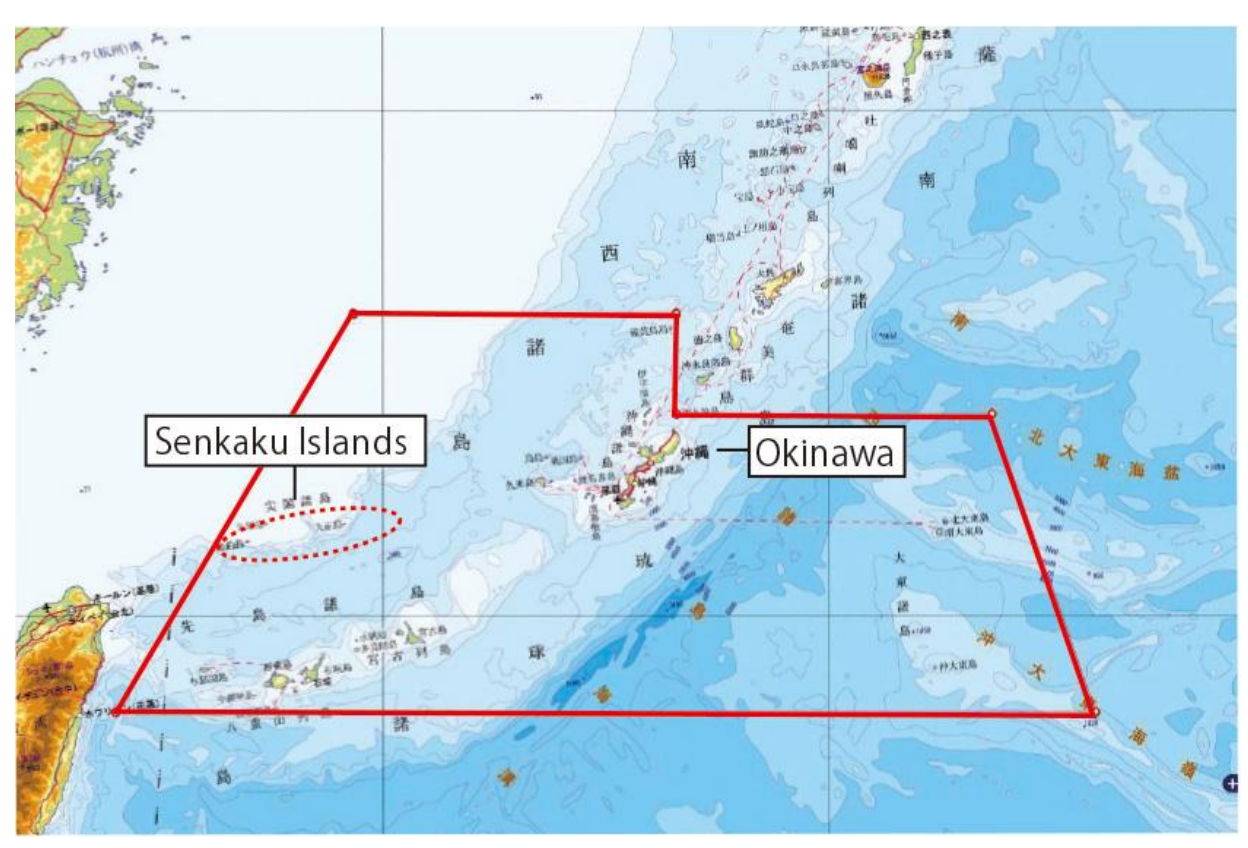

69 Monika Chansoria, "Why China Is Stepping Up Quest for the Senkakus in 2018," Japan Forward, February 1, 2018. At https://jpan-forward.com/why-china-is-stepping-up-quest-for-the-senkakus-in-2018/. See also Chansoria, China, Japan and Senkaku Islands: Conflict in the East China Sea Amid an American Shadow (New York/Oxford: Routledge, 2018). 
With the 1951 Treaty of Peace with Japan (the San Francisco Treaty), U.S. control of Diaoyu/Senkaku continued as part of U.S. administration of Okinawa. "The Treaty did not mention the Senkakus (Diaoyu/Diaoyutai), but it referred to other locations that had reverted to Chinese control or which China claimed. These included Taiwan and the Pescadores (off the western coast of Taiwan), as well as the Spratlys and the Paracels (both in the South China Sea)." In short, the signators of the Treaty (which excluded the People's Republic of China and the Soviet Union) did not recognize the islands as part of China, and the Chinese did not treat the islands as part of Taiwan until 1970, when it became clear that the U.S. intended to return Okinawa to Japan.

The U.S. transferred administrative control of Diaoyu/Senkaku to Japan in 1972 as part of the Okinawa Reversion Treaty, which restored Japanese sovereignty over Okinawa. The Treaty signed in June 1971, entering into force in May 1972 - clearly intended to include Diaoyu/Senkaku, making reference to "the Ryukyu Islands and the Daito Islands," defined all territories for which any powers of administration, legislation and jurisdiction were accorded to the United States of America under Article 3 of the Treaty of Peace with Japan." ${ }^{\text {"1 }}$ A letter of understanding of October 20, 1971 by Robert Starr, Acting Assistant Legal Advisor for East Asian and Pacific Affairs, stated that "the terms and conditions for the reversion of the Ryukyu Islands" included the Senkakus. ${ }^{72}$ However, the Nixon Administration (and subsequent U.S. administrations), in returning control of the islands to Japan, remained neutral on the issue of ultimate sovereignty, drawing a distinction between recognition of "sovereignty" and recognition of "administrative control. "73 At the same time, and somewhat confusingly, U.S. administrations since the 1970s have asserted that an attack on Diaoyu/Senkaku by China or any other third party would elicit an American response under the 1960 U.S.-Japan Security Treaty. In 2010, at a time of heightened Sino-Japanese tensions over the islands, then-Secretary of State Hillary Clinton stated that "with respect to the Senkaku Islands. The United States has never taken a position on sovereignty, but we have made it very clear that the islands are part of our mutual treaty obligations, and the obligation to defend Japan." ${ }^{34}$ American support for Japan has stiffened since 2012, when the U.S. Congress inserted into the FY2013 Defense Authorization

\footnotetext{
70 Mark E. Manyin, "The Senkakus (Diaoyu/Diaoyutai) Dispute: U.S. Treaty Obligations," Congressional Research Service (R42761), October 14, 2016, p.4.

$71 \mathrm{lbid}$.

72 See U.S. Congress, Senate Foreign Relations Committee, The Agreement between the United States of America and Japan Concerning the Ryukyu Islands and the Daito Islands, hearing on the Okinawa Reversion Treaty, $92^{\text {nd }}$ Congress, $1^{\text {st }}$ session, October 27, 1971 (Washington: GPO, 1971), p.91.

${ }^{73}$ Wrote Robert Starr, in his letter of understanding: "The Governments of the Republic of China [Taiwan] and Japan are in disagreement as to sovereignty over the Senkaku Islands. You should know as well that the People's Republic of China has also claimed sovereignty over the islands. The United States believes that a return of administrative rights over these islands to Japan, from which the rights were received, can in no way prejudice any underlying claims. The United States cannot add to the legal rights Japan possessed before ot transferred administration of the islands to us, nor can the United States, by giving back what it received, diminish the rights of other claimants. The United States has made no claim to the Senkaku Islands and considers that any conflicting claims to the islands are a matter for resolution by the parties concerned." Ibid.

74 "Hillary Rodham Clinton Remarks Following Signing Ceremonies," Hanoi, Vietnam, October 30, 2010.
} 
Act a resolution restating Washington's position: "The unilateral action of a third party will not affect the United States' acknowledgement of the administration of Japan over the Senkaku Islands."75

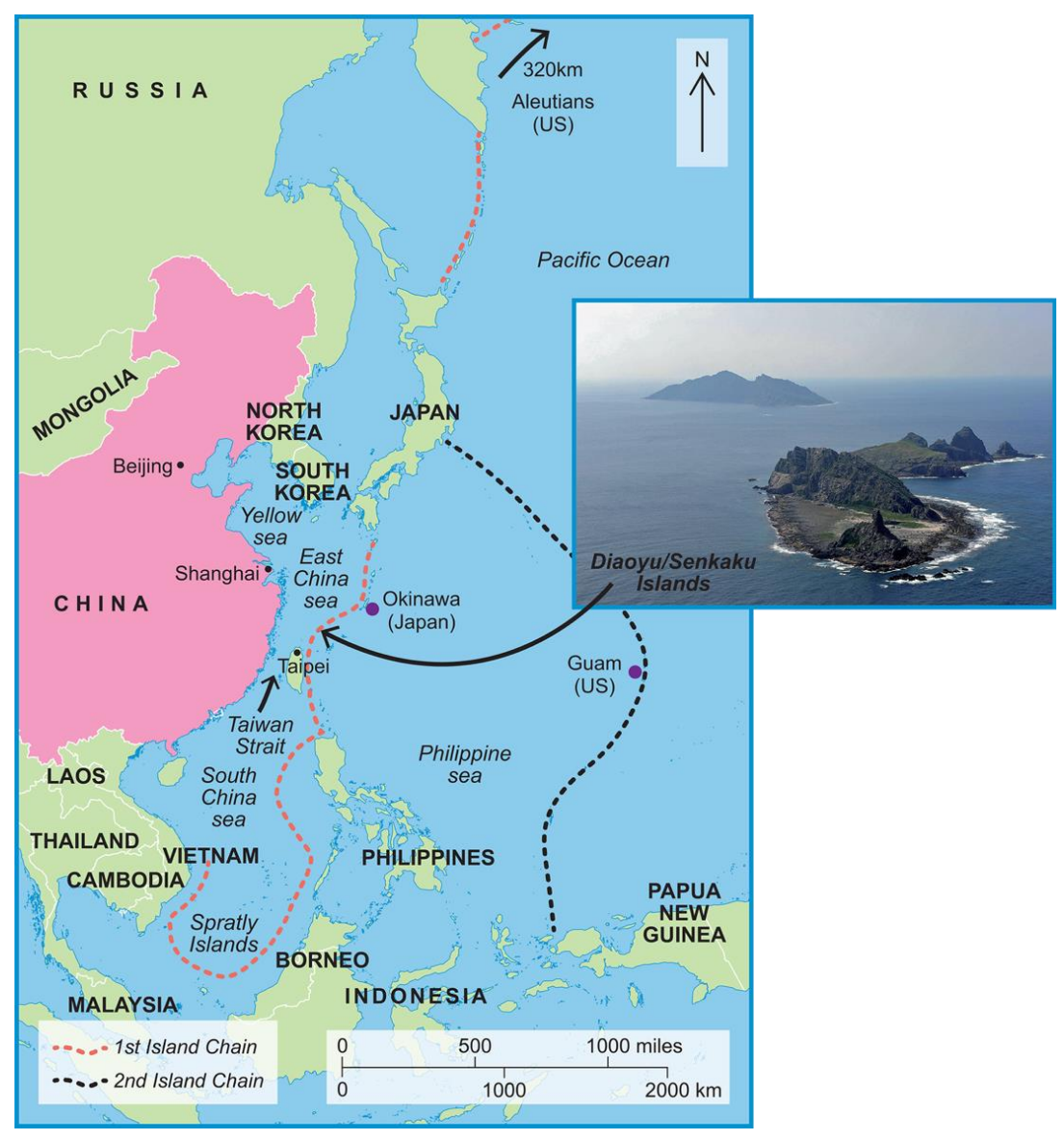

This (2012) is the same year in which the confrontation between China and Japan over Diaoyu/Senkaku dramatically intensified. The islands had been under private Japanese ownership, but in September 2012 the Democratic Party of Japan (DPJ) government of Yoshihiko Noda purchased three of the islands (Uotsurishima, Kita-Kojima and Minami-Kojima) from the Kurihara family for $¥ 2.05$ billion ( $\$ 26.2$ million), essentially nationalizing them. The ostensible justification was to prevent conservative nationalist Tokyo Governor Shintaro Ishihara from using municipal funds to buy the islands. China, however, would have no part of it, and reacted fiercely to what it regarded as a Japanese government provocation, characterizing Tokyo's action as "illegal and invalid." The People's Liberation Army Daily characterized the purchase as "the most blatant challenge to China's sovereignty since the end of World War II."76 On the same day that Tokyo announced the purchase, China updated its claim to its territorial baselines to include Diaoyu/Senkaku. Three days later, consistent with the U.N. Convention on Law of the Sea

75 See Manyin, "The Senkaku (Diaoyu/Diaoyutai) Dispute" (note 61), p.7.

76 Quoted in "China Sends Patrol Ships to Island Held by Japan," CSNSNEWS.com, September 11, 2012. See also Mure Dickie \& Kathrin Hille, "Japan Risks China's Wrath over Senkaku," Financial Times, September 10, 2012. 
(UNCLOS), the PRC filed with the U.N. extending its continental shelf in the East China Sea to the Okinawa Trough, thereby incorporating the islands. ${ }^{77}$ After dispatching marine surveillance ships and, later, naval vessels to the vicinity of the islands, China in November 2013 extended its Pacific Air Defense Identification Zone (ADIZ) to the airspace over them, an action that was protested (and defied) by both Japan, South Korea and the United States. The intervening years have seen an at-times steadily escalating confrontation between Tokyo and Beijing, despite a November 2014 agreement stipulating development of a "strategic relationship of mutual benefit" and establishment of a crisis management mechanism. ${ }^{78}$ Writes Captain Taul (Pete) Pedrozo (USN, Ret.),

"Since 2013, Chinese intrusions into Japan's claimed airspace and waters around the islands have become commonplace in an apparent effort to demonstrate that Japan does not exercise effective administrative control of the islands. These increased incursions raise the possibility of a miscalculation or other unintended consequence. In the three-month period between July 1 and September 30, 2015, JSDF [Japan Self-Defense Force] fighters scrambled 117 times to intercept Chinese aircraft in the vicinity of the Senkakus . . . In an apparent show of force, eleven Chinese military aircraft - eight bombers, two surveillance planes and an early-warning aircraft conducted a drill near Miyako and Okinawa in November 2015 to 'improve its long-range combat capabilities,' prompting the JSDF to intercept and monitor the aircraft."79

China's sea-borne forces have also been involved in such exercises, and in efforts to protect Chinese fishing vessels operating in the vicinity of Diaoyu/Senkaku. In early 2018, the Japanese Defense Minister Itsunori Onodera accused China of deliberately escalating tensions after a PLAN (People's Liberation Army Navy) submarine and Hiangkai-2 class frigate were observed close to the islands, the first such occurrence since $2016 .{ }^{80}$ In Beijing's view, its operations are a response to what Japan and the U.S. are doing, including an August 2017 U.S. Air Force/Japan Air Self-Defense Force drill near the islands.

Western international relations specialists are inclined to view this history in terms of either a neorealist or neo-liberal interpretation of the confrontation between China and Japan (or the triangular relationship between China, Japan and the U.S.). Diaoyu/ Senkaku lies, after all, in a strategically important position adjacent to one of the world's busiest shipping lanes (lanes critically important to China, Japan and South Korea), and it is located atop a proven large reservoir of oil and

\footnotetext{
77 See "Statement of the Government of the People's Republic of China on the Baselines of the Territorial Sea of Diaoyu Dao and its Affiliated Islands," www.fmprc.gov.cn/eng/zxxx/t968769.htm.

78 See Taboola, "Five Years after Nationalization of the Senkaku Islands," Japan Times, September 11, 2017, at: www.japantimes.co.jp/opinion/2017/09/11/editorials/five-years-nationalization-senkaku-islands/\#.WzAyVi2ZNBw. ${ }^{79}$ Raul (Pete) Pedrozo, "International Law and Japan's Territorial Disputes," Review of Island Studies, February 6 , 2018, at: https://www.spf.org/islandsstudies/research/a00018r/.
}

80 See Chonsoria, "Why China Is Stepping Quest for the Senkakus in 2018” (note 60), pp.1-3. 
natural gas reserves, many of which - like the islands themselves - lie in the zone where China's and

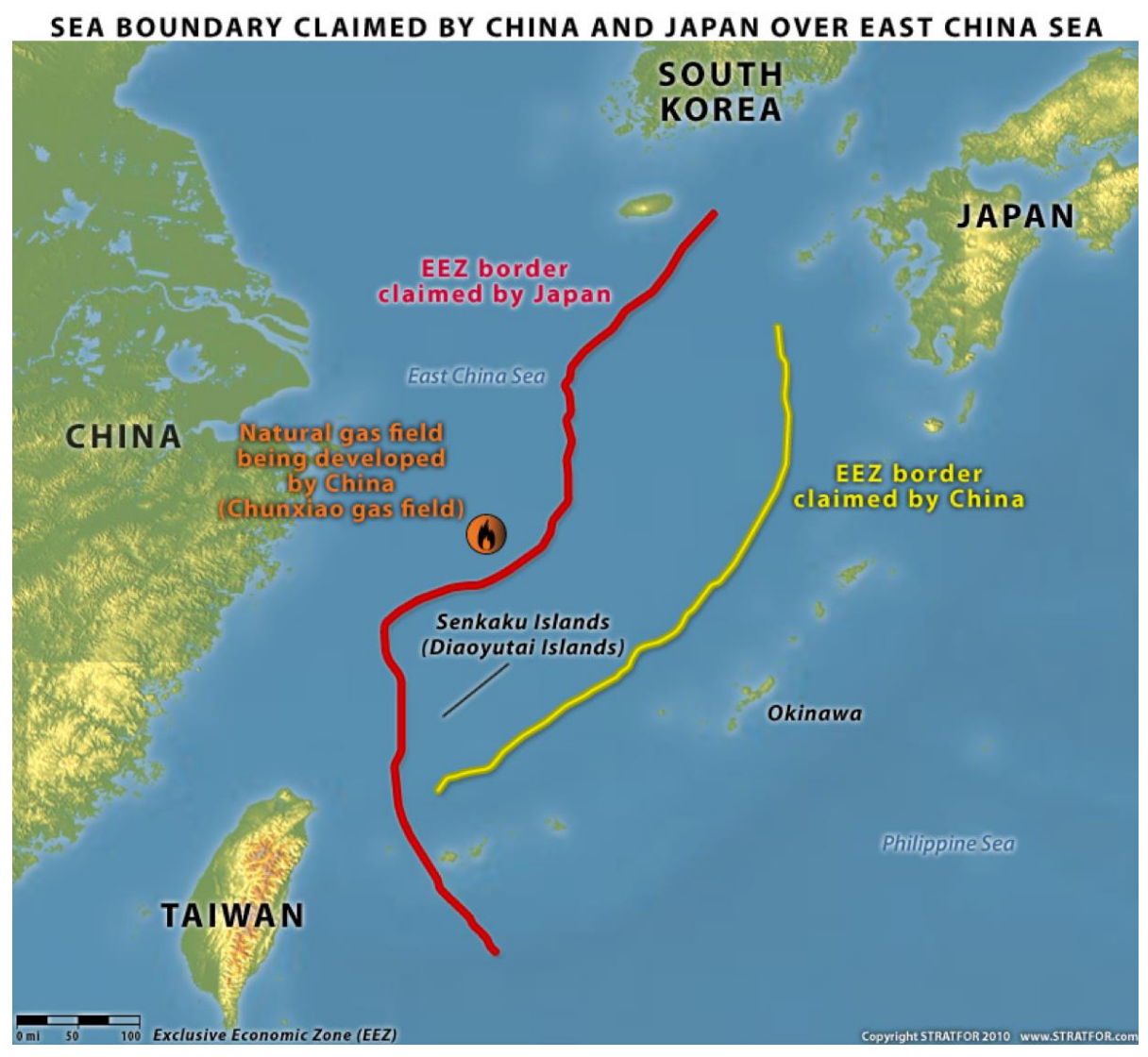

Copyright STRATFOR

Japan's EEZ's (Exclusive Economic Zones) overlap. Yet, in truth, the islets are of negligible strategic importance to Japan, given the relatively close proximity of Yonaguni Island (108 km from the east coast

of Taiwan), which is populated and has a Japanese military radar facility. It is also difficult to make the

case that the islands are strategically vital to the PRC, despite nearby shipping lanes. The islands are, of course, adjacent to the Chunxiao gas field and other strategic energy reserves. However, absent territorial nationalism, energy exploitation arrangements between China, Taiwan and Japan would not likely center on administration of (or sovereignty over) Diaoyu/Senkaku. 
Amrita Jash is close to the truth when she observes that the substance of the Diaoyu/Senkaku conflict "is neither the economic nor the strategic value of the islands, but rather their emotional significance for China that defies rational calculation." ${ }^{81}$ As she argues,

"What explains China's assertive behavior is its identity vis-à-vis Japan, which is deeply embedded in historical memories - dominated by a sense of inferiority and the humiliation suffered during Japan's invasion of China. The strong sentimental rhetoric of a 'victimized China' in the hands of an 'aggressive Japan' dominates the Chinese psyche and significantly regulates China's behavior towards Japan ... These tensions make the Diaoyu/Senkaku islands a testing issue between China and Japan and their clash of identities." ${ }^{2}$

For Japan, too, the islands - as with the Northern Territories and Dokdo/Takeshima - are an appurtenance of historical identity and a reminder that the country wants to stop paying recompense for its misadventures in the 1930s and 40s. Territorial issues (as in all three of the case studies discussed here) have had deep traction with Japanese public emotions.

Writing in 2010, M. Taylor Fravel argued that armed conflict over Diaoyu/Senkaku had been avoided, and Beijing had committed itself to "state inaction" over the issue, precisely because the stakes were moderately low, and also because (1) Japan and the U.S. wielded effective deterrence, (2) Japan had de facto control of the islands, (3) both sides did not wish to damage their political reputation in the region, and (4) there were effective mechanisms of dispute management. ${ }^{83}$ Such dispute management, he argued, included limiting access to the islands, avoiding social mobilization with respect to them, ensuring (on Japan's part) their continued demilitarization, and preserving an outward U.S. policy of neutrality with respect to the sovereignty issue. ${ }^{84}$ Clearly, some of these conditions have subsequently changed, as Fravel himself has more recently acknowledged. ${ }^{85}$ The Japanese government's purchase of three of the islands in 2012 was a game changer. The deeper change, however, has been in China's strategic position, which has grown stronger with every passing year.

\section{CONCLUSION}

Stephen Quackenbush, in his analysis of the sources of interstate conflict, rank-orders six critical factors that are likely to lead to military confrontation and state-to-state violence: (1) the presence of geographical contiguity; (2) the absence of alliances; (3) the absence of more advanced

\footnotetext{
81 Amrita Jash, "Diaoyu/Senkaku Islands Dispute: Identity versus Territory," Policy Forum, January 11, 2016, p.2. At: https://www.policyforum.net/diaoyusenkaku-islands-dispute-identity-versus-territory/.

82 lbid.

${ }^{83}$ See M. Taylor Fravel, "Explaining Stability in the Senkaku (Diaoyu) Islands Dispute," in Gerald Curtis, Ryosei Kokubun @ Wang Jisi, Getting the Triangle Straight: Managing China-Japan-U.S. Relations (Washington, D.C.: Brookings Institution Press, 2010), pp.149-151.

${ }^{84}$ See ibid., pp.151-156.

${ }^{85}$ See M. Taylor Fravel, "Explaining China's Escalation over the Senkaku (Diaoyu) Islands," Global Summitry, vol.2, no.1 (June 2016), pp.24-37.
} 
economies; (4) the absence of a democratic polity; (5) the absence of overwhelming preponderance by a single state or coalition of states; and (6) the absence of a major power. ${ }^{86}$ By this standard, the three cases I have looked at here meet only the first and fifth conditions. All three conflicts involve (1) states with committed alliances, (2) at least one state that is a democracy, (3) states with advanced economies, and (4) states that are themselves, or are tied to, a major power. The Quackenbush analysis should indicate, then, that there is a low probability of armed conflict resulting from the Northern Territories, Dokdo/Takeshima or Diaoyu/Senkaku disputes. This would seem to be consistent with much of the analysis summarized here, particularly M. Taylor Fravel's evaluation in his piece on "Explaining Stability in the Senkaku (Diaoyu) Islands Dispute." 87 But, how certain can we be of this conclusion? By Quackenbush's standard, a number of conflicts outside of the developing world (including both world wars) should have had a lower probability of occurring. But, they occurred anyway, and in the case of the two world wars it is difficult to discount the impact of factors such as raw nationalism.

Fravel, in his Strong Borders Secure Nation, provides a convincing rationalist (i.e., neo-realist) analysis of the factors that bear on territorial disputes. In his analysis, states are confronted with three generic strategies in dealing with territorial disputes: (1) a "delaying" or conflict avoidance strategy, "whereby states maintain their territorial claims through public declarations but neither offer concessions nor use force" (in other words, they "do nothing"); (2) a "cooperation" strategy, which "excludes the threat or use of force and involves an offer either to transfer control of some or all of the contested land to the opposing side or to drop claims to land held by the other state;" or (3) an "escalation" strategy, which "involves the threat or use of force to seize land or coerce an opponent." 88 Governments and state leaders rationally calculate their approach to a territorial dispute on the basis of the value of the contested land, the degree of both international and domestic security or insecurity that they are experiencing (including the need to secure allies in a confrontation or to shore up their domestic political position), their relative strength vis-à-vis the adversary, and their "claim strength" in the dispute, as determined by a mix of factors. The paradigm Fravel employs in evaluating China's territorial disputes with its neighbors is summarized in the table below. The analysis is counter-intuitive in some

\footnotetext{
86 See Stephen L. Quackenbush, International Conflict: Logic and Evidence (Washington, D.C.: CQ Press, 2014), pp. 2-19.

87 See Fravel, "Explaining Stability in the Senkaku (Diaoyu) Islands Dispute" (note 12), passim.

88 Fravel, Strong Borders Secure Nation, p.12.
} 


\section{COOPERATION AND ESCALATION IN TERRITORIAL DISPUTES ${ }^{89}$}

\begin{tabular}{|c|c|c|c|}
\hline & $\begin{array}{c}\text { Value of } \\
\text { Contested Land }\end{array}$ & $\begin{array}{l}\text { Claim Strength } \\
\text { in a Dispute }\end{array}$ & $\begin{array}{l}\text { Security } \\
\text { Environment }\end{array}$ \\
\hline $\begin{array}{l}\text { Sources of } \\
\text { Cooperation }\end{array}$ & $\begin{array}{l}\text { A state is more likely } \\
\text { to compromise over } \\
\text { over less valuable } \\
\text { land. }\end{array}$ & $\begin{array}{l}\text { A state is more likely } \\
\text { to compromise when } \\
\text { its relative position in } \\
\text { a dispute is stable, } \\
\text { strong, or strengthening. }\end{array}$ & $\begin{array}{l}\text { A state is more likely } \\
\text { to compromise when it } \\
\text { faces either internal or } \\
\text { or external threats to } \\
\text { its security. }\end{array}$ \\
\hline $\begin{array}{l}\text { Sources of } \\
\text { Escalation }\end{array}$ & $\begin{array}{l}\text { A state is more likely } \\
\text { to threaten or use } \\
\text { force over more } \\
\text { valuable land. }\end{array}$ & $\begin{array}{l}\text { A state is more likely to } \\
\text { to threaten or use force } \\
\text { when its relative position } \\
\text { in a dispute is declining. } \\
\text { A state with a weak claim } \\
\text { is more likely to use force } \\
\text { when its relative position } \\
\text { suddenly and temporarily } \\
\text { improves. }\end{array}$ & $\begin{array}{l}\text { A state is even more } \\
\text { likely to threaten or } \\
\text { use force if decline in } \\
\text { claim strength } \\
\text { coincides with internal } \\
\text { or external threats to } \\
\text { its security. }\end{array}$ \\
\hline
\end{tabular}

respects: stronger powers with greater claim strength are more likely to compromise because they feel more secure; weaker powers are apt to pursue escalation if they perceive that their relative position is weakening; and states facing external threats or internal instability are more likely to compromise. Unfortunately, while this model may apply relatively well to the twenty-three territorial conflicts involving China that comprise the bulk of Fravel's study, it does not apply all that convincingly in the three cases we have analyzed here.

The application of Fravel's model is only partly accurate in its explanation of the Kuriles dispute. The Yeltsin government in the 1990s saw itself confronted by significant internal stability problems, but - contrary to Fravel's model - did not seek to escalate in the dispute over the Northern Territories. However, with the arrival of Putin, Russia's position became indisputably "stable, strong, and strengthening," yet this did not at the same time generate a greater willingness to compromise. Japan experienced political stability under Koizumi, but its willingness to compromise declined since the days of Hashimoto, Obuchi and Mori. On the other hand, Japan's position on the Northern Territories issue had never been "stable, strong, and strengthening," and this generated considerable frustration both in the Foreign Ministry and on the

89 lbid., p.38. 
part of the Japanese public. Russia has redoubled its commitment to development of the Kuriles since Medvedev's first visit in November 2010. As with South Korea's physical possession of Dokdo, Russia's physical occupation of the four islands presented Tokyo with a challenge. The upshot, given Fravel's model, is that Moscow is in a position to compromise but is unlikely to do so. Little significant change in the status quo can be expected.

The application of Fravel's model to Dokdo/Takeshima also yields interesting results. Both protagonists (Japan and South Korea) are stable democracies, which ought to increase their willingness to compromise. However, stable democracy may also reduce the maneuverability of a government on an emotional territorial issue, particularly at a time of populist or nationalist politics. Although both Japan and South Korea face external security threats from North Korea and China, neither has experienced a significant change in its "claim strength" with regard to the Dokdo/Takeshima dispute. The medium-term prognosis is that posturing over Dokdo/Takeshima will continue, but little in the way of a breakthrough (or a breakdown) is likely to occur, though this may change once the actual extraction of gas hydrates begins (at that point Dokdo's value to both parties may be more than emotionally nationalistic or symbolic).

Like the ongoing dispute over the South China Sea (which I have not discussed here), the greater salience of the Diaoyu/Senkaku conflict is, more than anything else, a testament to China's rise as a successful regional hegemon. Contrary to Fravel's model, Beijing's emergence as a more secure power has made it increasingly less willing to compromise in the East China Sea. Similarly, Japan's evolution toward the status of a "normal" power (i.e., a power that unapologetically deploys military instruments capable of projecting its will) has, if anything, reinforced its determination to take a firm stand on the islands. The backdrop to these developments has been the relative decline of U.S. power in the region, underscored - in part by official U.S. "neutrality" with respect to both the Diaoyu/Senkaku and Dokdo/Takeshima sovereignty issues.

The lesson in all three case studies is clear: First, the constructivists are correct in asserting the power of national "identity" issues, though identity alone - absent the "material" factors focused on by neorealists and neoliberals - provides an incomplete explanation of the conflicts analyzed here. Second, nationalism and populism are powerful forces that easily latch onto territorial conflicts for their symbolic value, and this may be particularly true of maritime disputes, despite the (as noted earlier) more ambiguous nature of maritime disagreements in international law. Third, states do not always rationally calculate their short- and long-term interests on the basis of the information they have available to them or on the basis of the power and resources at their disposal. In particular, they do not rank-order their interests in the manner prescribed by realist, neo-liberal or other rationalist models of state behavior, even allowing for legitimate differences of opinion among state elites about the prioritization of goals. Indeed, the primary thrust of the constructivist school of international politics is to dispel the notion that states always rationally order their strategic goals in a way that maximizes the realization of their interests. Fourth, it is in 
the interplay between a state's domestic and external environments that rationalist interpretations frequently break down. All states are to some degree "penetrated political systems," that is, states in which domestic political cleavages are significantly impacted by external, foreign-policyrelated conditions and events, and in which domestic passions influence the conduct of foreign policy. ${ }^{90}$ Fifth, nationalism is a particularly powerful force in East Asia, though its importance has until recently been often underappreciated. As recently as 2002, Hemmer and Katzenstein, in a paean to classical U.S.-centric thinking, attributed the absence of an East Asian multilateral security organization (an "Asian NATO") to U.S. policy and the cultural disposition of the American foreign policy elite toward Asians. ${ }^{91}$ East Asian nationalism, framed largely as regional antipathy to Japan, received attention in three thinly argued paragraphs. ${ }^{92}$ With thinking such as this, it is little wonder that U.S. policy has so frequently run into trouble, or that Washington has experienced difficulty engaging the region's national and territorial antagonisms.

Japan, China, South Korea and Russia have likely paid a disproportionate price for their intransigence on these three islands issues. No rational explanation of their foreign policies could justify the impact of the Southern Kuriles, Dokdo/Takeshima and Diaoyu/Senkaku disputes on the choices and opportunities available to them. One can only wonder at what choices might open up if Japan and Russia could pursue an unfettered relationship as investment (and geopolitical) partners, if Japan and South Korea could move beyond a primarily commercial relationship, and if China and Japan could achieve the kind of rapprochement that might lead to genuine regionalism. In all three cases public passions have been reinforced by political opportunism and short-term bureaucratic calculation. Unfortunately, Northeast Asia continues to be held hostage to populist nationalism, and maritime disputes over sparsely populated (or, in Diaoyu/Senkaku's case, unpopulated) islands have become the "poster children" for regional conflict.

International relations scholarship on the subject of maritime disputes often holds that such disputes - consistent with neo-realist thinking - will be subordinated to larger foreign policy priorities. Neo-liberals, focusing on interdependence and "trade dependency," likewise hold that resolution of territorial conflicts will be sidelined, sublimated or delayed in order to accommodate larger economic concerns. We have seen in the three cases discussed here that such assumptions are not always valid. The world in 2018 is awash in a wave of renewed populist nationalism (witness the rise of Trump in the U.S., Putin in Russia, Xi in China, Modi in India, Erdogen in Turkey, Abe in Japan, etc.), and the role that nationalist sentiment plays in obstructing the resolution of East Asia's maritime disputes is fully consistent with this. The Northern Territories, Dokdo/Takeshima and Diaoyu/Senkaku are not only examples of East Asia's fractiousness, but also - in a very real sense - symbols of their time.

90 See Wolfram F. Hanrieder, "Compatibility and Consensus: A Proposal for Conceptual Linkage of External and Internal Dimensions of Foreign Policy," American Political Science Review, December 1967.

91 See Christopher Hemmer \& Peter J. Katzenstein, "Why is There No NATO in Asia? Collective Identity, Regionalism, and the Origins of Multilateralism," International Organization, vol.56, no.3 (Summer 2002), pp.575-603.

92 See ibid., pp.581-582. 